\title{
Evaluating jointness of multifunctional agriculture: the educational function of dairy farming in Japan
}

\author{
Y. Ohe \\ Department of Agricultural Economics, Chiba University, Japan
}

\begin{abstract}
The significance of the educational function of multifunctionality has been pointed out as a new role of agriculture. It lets people recognise rural resources such as rural heritage and farm life and it is expected to eventually lead to a wellbalanced resource allocation nationwide between urban and rural areas. However, the connection between farm structure, especially aspects of farming production, and this function has been little clarified either from conceptual or empirical viewpoints. This point is crucial in exploring new possibilities of agriculture and in designing policy measures to promote diversification in connection with multifunctionality. Thus, to clarify this relationship it is necessary to investigate how the jointness of farming production and this multifunctional activity is actually determined by the farm structure. To approach this aim, firstly, we give conceptual consideration to characteristics of educational function. Secondly, based on that consideration, we conduct comparative analysis on two types of Japanese dairy farms with an open farm policy for visitors, Dairy Educational Farms and Open Dairy Farms, to clarify statistically their multifunctional activities and the characteristics of these farms. The results are as follows. The educational function of dairy farming has no correlation with farm size, which means the externality is decoupled. The jointness is not fixed, but variable in terms of both technical and institutional aspects. Among other things, family farms certified as Dairy Educational Farms have firmer technical and institutional jointness, therefore there can be less substitution of other similar educational services. Consequently, policy implications are as follows: the educational function does not have a productionstimulating effect and a policy program aiming at promotion of this function is effective especially for family farms.

Keywords: multifunctionality of agriculture, externality, jointness, educational function, dairy farming, farm policy, Japan.
\end{abstract}




\section{Introduction}

The significance of the educational function has been pointed out as a new role of agriculture (Shichinohe et al. [6]) and is considered as one of the functions in multifunctionality, or the externality generated by agriculture (Ohe [3]). To our knowledge, however, very little has been explored with regard to this educational function in spite of recent intensive research on multifunctionality issues (for multifunctionality issues, see OECD [4, 5] and Van Huylenbroeck and Durand [7] from European perspective and Ohe [2] from the Japanese perspective.). One feature of the educational function that differentiates it from other multifunctional activities is that its object is human resources, not the rural environment and resources. It is expected that the educational function lets people recognise rural resources, such as rural heritage and farm life, and eventually leads to a well-balanced resource allocation nationwide between urban and rural areas.

However, the connection between farm structure, especially aspects of farm production, and this function has been little examined either from conceptual or empirical viewpoints.

Thus, to clarify this relationship between farm structure and the educational function, it is necessary to investigate how the jointness of farming production and this multifunctional activity is actually determined by the farm structure. Whereas discussions on the jointness of multifunctionality so far have tended to take place under the implicit assumption of a fixed pattern of jointness, it is natural that actual jointness will vary depending on farm structure. Another point is that we should examine institutional jointness (for institutional jointness, see Hagedorn [1]), which has been little explored, because if institutional jointness is very adaptable to farm policy guidance, policy promotion of multifunctional activity will be made more effective by paying more attention to institutional jointness.

\section{Characteristics of educational function as multifunctionality of agriculture}

First, we characterise the educational function as multifunctionality in comparison with other functions such as land preservation and landscape forming. The difference is the object of its effects. Land preservation and landscape forming functions directly affect rural resources and the environment, but indirectly affect human resources as economic units. In contrast, the effects of the educational function directly work on human resources. This point has commonality with that of the recreational function.

Second, we discuss features of the educational function in comparison with educational issues in economics. In economics the issues of education are mainly discussed under the framework of human capital such as measurement of the internal rate of return for educational investment or of how much educational investment accrues a productivity difference from an initial point, etc. We characterise the educational function in comparison with job training in farm 
operation where the human capital framework is applicable. The comparison reveals that the theory of traditional human capital cannot adequately address the issue of educational function in farming because of several unique points.

Table 1: $\quad$ Comparison of two educational effects of agriculture.

\begin{tabular}{|c|c|c|}
\hline Item & Farming experiences & Farming skill training \\
\hline Type of education & Consumer education & Job training \\
\hline $\begin{array}{c}\text { Related multifunctionality } \\
\text { Externality accompanied by } \\
\text { production activity }\end{array}$ & Educational function & None \\
\hline $\begin{array}{c}\text { Suitable age group } \\
\text { knowledge and skills }\end{array}$ & Compulsory education age & Youth and middle age \\
\hline Effect & No & Yes \\
\hline $\begin{array}{c}\text { Obsolesce of obtained } \\
\text { Suitable technology }\end{array}$ & Rising efficiency of rural \\
resource use & Rising agricultural productivity \\
\hline $\begin{array}{c}\text { Suble type of technology } \\
\text { Out-dated technology }\end{array}$ & $\begin{array}{r}\text { Well-rounded, fundamental } \\
\text { technology }\end{array}$ & $\begin{array}{c}\text { Specific, specialised, applied } \\
\text { technology }\end{array}$ \\
\hline
\end{tabular}

Table 1 contrasts the features of two educational efforts. First, the target of farm job training is naturally to raise skills in farm operation among farmers and those who want to be farmers. Therefore, the aim is to improve farm productivity and to efficiently manage a farming operation as in the industrial sector by acquiring techniques that range from the fundamental to the top-notch. Human capital framework is surely effective here. This is because the effects of the educational investment in this training are embodied as skills acquired by individuals of production age who most often receive such education. Furthermore, there is another commonality in this type of job training in that acquired skills will become obsolete along with technological progress, although some skills may be improved in the course of accumulated job experience.

On the contrary, the effects of farming experiences will not become seriously obsolete because the purpose is different from that of job training aimed at enhancement of productivity. Those who seek farming experiences do not have this specific aim even though farming experiences increase interest in farming as an occupation. The target population consequently consists of consumers living in urban areas rather than producers or trainees to become producers. In this sense, it can be said that farm experience services have the aspects of consumer education more than of producer education.

These services are often implemented as a social experience curriculum in elementary and junior high schools. Thus the target population is those engaged in compulsory education and who are of a pre-production age. The purpose is to reduce food waste and promote healthy dietary habits, as well as helping people recognise the significance of nearly abandoned or forgotten traditional rural and 
food resources in the local community. Those are short-term effects. If waste of food resources is reduced and an understanding of rural resources is disseminated, then negative externalities such as issues related to excessive food waste in urban areas will be eased. This will eventually lead to realisation of more efficient resource allocation in the entire society through rectifying the spatial imbalance between rural and urban areas. Those are long-term effects.

Originally, households and the local community played these educational roles. However, because of deterioration of educational capabilities of both households and communities, we postulate that dairy farmers partially substitute for these entities by providing farming experience services. Especially, the educational function of dairy farming has a unique aspect that crop farming lacks since dairy farming provides opportunities to come into contact with livestock. The effects of these services basically belong to the recipients. It is considered that the effect will be greater for the generation engaged in elementary education than for adults because the earlier the age of education, the greater the effects are because the externality of education will become greater.

Thus, the target population is mainly the young who are not experts in farming, so fundamental and general techniques tend to be preferred to specific and piecemeal cutting-edge technology. A broader range of techniques such as manually-performed work and self-sufficient farming and processing techniques that have been left behind over time can be learned during the farming experience in addition to the most advanced ones. Rather, it is safe to say that an obsolete manual labour operation is more suitable for learning the abcs of the production process than in a mechanised operation utilising the latest technology. Consequently, the retired elderly can contribute as teachers, and human resources in the rural community will be utilised, which is another effect of the educational function. As we have discussed above, the educational function as multifunctionality has unique aspects that the human capital theory of conventional economic framework will tend to miss.

\section{Unique aspects of jointness}

We consider here the jointness that produces the educational function. There are two types of jointness that we should examine: technical jointness and institutional jointness. Technical jointness is observed in the educational function as in other multifunctional activities because it is jointly produced with farm products and is inseparable from the agricultural production process. Every multifunctional activity has this aspect. The example here is farming experience services offered by farmers to visitors.

Another point we have to consider is institutional jointness. This jointness is connected with institutional aspects. First, the Educational Dairy Farm program is one policy institution for the promotion of educational services. The attitude of farmers toward this program determines what management policy they have for provision of educational services. For instance, consider a farmer with a good understanding of the program and a motive for providing educational services to visitors. The jointness between this multifunctionality and farm production will 
be stronger than in cases of those farmers not having such an understanding and motivation. This program provides an opportunity for highly motivated farmers to raise this multifunctionality. This is evidence that institutional jointness is determined by institutional factors. The second point we should take into account is the type of farm management. For instance, it is very likely that corporate farms act differently from family farms in terms of the educational function under different resource constraints and farmer's management policies.

In this respect, the educational function has similarity with the recreational function, which is enhanced by the rural tourism program. Rural tourism is, however, an activity that can be offered as private goods and therefore enables farmers to internalise the externalities to realise income, while the educational function is not always possible for farmers to offer as private goods, which means the externalities of the educational function will end up with incomplete and partial internalisation. This tendency partially comes from the characteristics of education itself because if complete internalisation will be attained, then the product would no longer be education, but pure private goods such as recreational goods. Thus, this incomplete and partial internalisation is a feature of the educational function.

The above consideration indicates that not only technical jointness, but also institutional jointness should be counted in the evaluation of the educational function. If the empirical analysis below can reveal that institutional jointness takes an important role, this leads to a different policy perspective from that only focused on technical jointness. The reason is that in this case policy emphasis should be placed more on institutional farm policy design rather than farm policy on technical issues.

\section{Data and methods}

Data were obtained from the membership list of Open Dairy Farms (as of March 2004, 127 membership farms, Japan Dairy Council). Open Dairy Farms is a national group of dairy farmers who conduct an open-farm policy for visitors from the outside, which started in 2000 in Japan. Most of these farmers are also certified as operators of Educational Dairy Farms, which started in the same year with the aim of providing farming experience services to visitors, in particular to school children and other youngsters. Generally speaking, among the Open Dairy Farms, Educational Dairy Farms are considered more inclined to offer educational services to visitors. Data obtained include the size of the dairy herd, activities offered as a farming experience and rural tourism activity. However, data on factor input relationships, such as land holdings and kinds of facilities, land use, family labour, and information related to production costs, are not available. For this reason, direct estimations of the production function and other cost functions for economies of scope and scale are not possible. Only indirect conjuncture is possible after the statistical analysis described below, which is a constraint of this data. Despite this constraint, no other data are available for detailed examination of the relationship among farm diversification, educational function and farm structure from a nationwide perspective. We conducted a 
statistical examination of jointness, farm diversification and farm structural factors. Then we discuss policy implications for promoting the educational function and farm diversification.

Table 2: $\quad$ Comparison between dairy educational farms and open dairy farms.

\begin{tabular}{|c|c|c|c|c|c|c|}
\hline \multirow{2}{*}{ Item } & \multirow{2}{*}{ Factor } & \multicolumn{2}{|c|}{ Educational dairy farms } & \multicolumn{2}{|c|}{ Non educational dairy farms } & \multirow{2}{*}{ Test result } \\
\hline & & $\%$ farms & Sample size & $\%$ farms & Sample size & \\
\hline \multirow[t]{4}{*}{ Type of farm } & Family farm & 58.5 & 55 & 57.1 & 20 & - \\
\hline & Family corporate farm & 16.0 & 15 & 25.7 & 9 & - \\
\hline & Non-family corporate farm & 25.5 & 24 & 17.1 & 6 & - \\
\hline & Total & 100.0 & 94 & 100.0 & 35 & n.s. \\
\hline Farm size & Herd size & 137.8 (cows) & 85 & 95.9 (cows) & 29 & n.s. \\
\hline \multirow{4}{*}{$\begin{array}{l}\text { Person in charge } \\
\text { of educational } \\
\text { service }\end{array}$} & Owner operator & 37.2 & 35 & 31.4 & 11 & - \\
\hline & Family member & 35.1 & 33 & 40.0 & 14 & - \\
\hline & Employee & 27.7 & 26 & 28.6 & 10 & - \\
\hline & Total & 100.0 & 94 & 100.0 & 35 & n.s. \\
\hline \multirow[t]{2}{*}{ Parking capacity } & Cars & 90.3(cars) & 83 & 26.0 (cars) & 31 & $* * N^{a)}$ \\
\hline & Buses & 6.5 (buses) & 65 & 3.5 (buses) & 23 & $+\mathrm{N}^{\mathrm{a})}$ \\
\hline $\begin{array}{l}\text { Internet } \\
\text { accessibility }\end{array}$ & Own website & 41.5 & 39 & 34.3 & 12 & n.s. \\
\hline \multirow{3}{*}{ Diversified activity } & Farm shop & 43.6 & 41 & 45.7 & 16 & n.s. \\
\hline & Restaurant & 30.9 & 29 & 5.7 & 2 & $* * *$ \\
\hline & Lodging facility & 33.0 & 31 & 28.6 & 10 & n.s. \\
\hline \multirow{10}{*}{$\begin{array}{l}\text { Farming } \\
\text { experience service }\end{array}$} & Dairy operation experience & 63.8 & 60 & 28.6 & 10 & $* * *$ \\
\hline & Farming experience & 36.2 & 34 & 22.9 & 8 & + \\
\hline & Tour of farm yard & 59.6 & 56 & 34.3 & 12 & $* *$ \\
\hline & Contact with livestock & 45.7 & 43 & 20.0 & 7 & $* * *$ \\
\hline & Milking & 71.3 & 67 & 31.4 & 11 & $* * *$ \\
\hline & Horseback riding & 19.2 & 18 & 5.7 & 2 & $* *$ \\
\hline & Butter-making & 61.7 & 58 & 22.9 & 8 & $* * *$ \\
\hline & Cheese-making & 20.2 & 19 & 8.6 & 3 & + \\
\hline & Ice cream-making & 30.9 & 29 & 14.3 & 5 & $*$ \\
\hline & No. provided services & 4.8 (items) & 94 & 2.2 (items) & 35 & $* * * E^{a)}$ \\
\hline \multirow{7}{*}{$\begin{array}{l}\text { Directly marketed } \\
\text { products }\end{array}$} & Fresh milk & 38.3 & 36 & 31.4 & 11 & n.s. \\
\hline & Ice cream & 45.7 & 43 & 34.3 & 12 & n.s. \\
\hline & Soft cream & 39.4 & 37 & 31.4 & 11 & n.s. \\
\hline & Cheese & 24.5 & 23 & 28.6 & 10 & n.s. \\
\hline & Yogurt & 31.9 & 30 & 17.1 & 6 & $*$ \\
\hline & Ham, sausage & 8.5 & 8 & 8.6 & 3 & n.s. \\
\hline & No. marketed products & 1.9 (items) & 94 & 1.5 (items) & 35 & n.s. ${ }^{\text {a) }}$ \\
\hline
\end{tabular}

Source: Membership list of the open dairy farms, as of March 2004, Japan Dairy Council.

Notes:1) $* * *, * *, *,+$ show significance levels, $1 \%, 5 \%, 10 \%, 20 \%$ (reference), n.s. shows no siginificance.

2) For test results, a) means $t$ test with $\mathrm{E}=$ equal variance and $\mathrm{N}=$ unequal varince while the Chi-square test or Fisher's exact test for small sample was used for others.

\section{Does institutional framework for educational function make a difference?}

We examined whether the institutional framework promoting the educational function would be connected with any differences in the educational function (Table 2). For this purpose, we classified the Open Dairy Farms into two 
categories to compare characteristics: those certified as Educational Dairy Farms (E-farms) and those not certified (NE-farms).

First, there was no difference in farm size between E-farms and NE-farms in terms of herd size of milk cows. Both have far larger herds than the national average, which was 58 milk cows per farm in 2003 according to Livestock Statistics of MAFFJ. This suggests that a certain level of farm size is a necessary condition for dairy farms to have an open door policy and to perform an educational function as well.

However, there are differences with statistical significance in the uptake ratio of farming experience services and in the number of farming experience services offered in the farmyard. That is to say, with regard to every farming experience service, a greater portion of E-farms than NE-farms offer the service. Consequently, the number of farming experiences offered by E-farms is larger than that by NE-farms (4.8 services for E-farms; 2.2 services for NE-farms; $1 \%$ significance). In short, E-farms actively offer farming experience services in compliance with the purpose of the educational farm program. Moreover, $31 \%$ of E-farms have restaurants while only $6 \%$ of NE-farms have such a facility $(1 \%$ significance), which indicates that E-farms successfully connect the educational function with farm diversification.

To summarise, it was revealed that E-farms were proactive in providing farming experience services. This indicates that institutional jointness for an educational function certainly exists and is enhanced by the institutional framework promoting it.

\section{Does management type of farms as an institutional framework make a difference?}

Here, we examine how the management type, which is a component of the institutional framework, affects educational function and farm diversification activities. We compare the differences among farm management types, that is, among family farms, family corporate farms, and non-family corporate farms. Among types of farms, family farms account for nearly $60 \%$ and family corporate farms and non-family corporate farms around $20 \%$, respectively. Results are shown in Table 3.

The results show apparent differences in various aspects, especially between family and corporate farms. First, non-family corporate farms are larger in farm size than the other two types because they include ranches owned by prefectures, municipalities, agricultural cooperatives, dairy products companies, and jointly by farmers. The portion of dairy farming is higher in family farms and lower in family corporate farms due to the larger variety of livestock holdings in the family corporate farms. As to who takes care of visitors, owner-operators of family farms tend to assume that role, but this portion drops in family corporate farms and further in non-family corporate farms ( $1 \%$ significance). This is because the latter can take advantage of division of labour with a larger labour force. Possession of a website differed between family and corporate farms $(1 \%$ significance): family farms $23 \%$, family corporate farms $67 \%$, and non-family 
corporate farms $60 \%$. These differences reflect the fact that, in general, corporate farms are active in diversification efforts. This is also evident from the higher percentages, with statistical significance, of such farms operating farm shops and restaurants, the portion of farms selling dairy products through direct marketing, and the number of products direct marketed. In other words, corporate farms, either family or non-family holdings, are clearly headed for diversification. In short, the larger the farm size is, the more diversification is oriented.

Table 3: $\quad$ Comparison of open dairy farms according to type of farm.

\begin{tabular}{|c|c|c|c|c|c|}
\hline \multirow[b]{2}{*}{ Item } & \multirow[b]{2}{*}{ Factor } & \multicolumn{3}{|c|}{ Type of farm( $(\%)$} & \multirow[b]{2}{*}{ Test result } \\
\hline & & Family farm & $\begin{array}{c}\text { Family } \\
\text { corporate }\end{array}$ & $\begin{array}{c}\text { Non-family } \\
\text { corporate }\end{array}$ & \\
\hline Sample size & - & 75 & 24 & 28 & - \\
\hline Type of farming & Dairy farming & 98.7 & 87.5 & 93.3 & $* *$ \\
\hline Farm size & Herd size & 81.8 (cows) & 140.2 (cows) & 263.8 (cows) & $* * *^{\mathrm{a})}$ \\
\hline \multirow{4}{*}{$\begin{array}{l}\text { Person in charge } \\
\text { of educational } \\
\text { service }\end{array}$} & Owner operator & 44.0 & 37.5 & 13.3 & - \\
\hline & Family member & 42.7 & 54.2 & 6.7 & - \\
\hline & Employee & 13.3 & 8.3 & 80.0 & - \\
\hline & Total & 100.0 & 100.0 & 100.0 & $* * *$ \\
\hline \multirow[t]{2}{*}{ Parking capacity } & Cars & 14.4 (cars) & 34.7 (cars) & 243.7 (cars) & $* * *^{\mathrm{a})}$ \\
\hline & Buses & 2.6 (buses) & 5.1 (buses) & 12.3 (buses) & $* * *^{\mathrm{a})}$ \\
\hline $\begin{array}{l}\text { Internet } \\
\text { accessibility }\end{array}$ & Own website & 22.7 & 66.7 & 60.0 & $* * *$ \\
\hline \multirow{3}{*}{ Diversified activity } & Farm shop & 18.7 & 75.0 & 83.3 & $* * *$ \\
\hline & Restaurant & 9.3 & 45.8 & 43.3 & $* * *$ \\
\hline & Lodging facility & 34.7 & 29.2 & 26.7 & n.s. \\
\hline \multirow{10}{*}{$\begin{array}{l}\text { Farming } \\
\text { experience service }\end{array}$} & Dairy operation experience & 62.7 & 37.5 & 46.7 & $*$ \\
\hline & Farming experience & 40.0 & 16.7 & 26.7 & $*$ \\
\hline & Tour of farm yard & 58.7 & 33.3 & 53.3 & $*$ \\
\hline & Contact with livestock & 49.3 & 8.3 & 36.7 & $* * *$ \\
\hline & Milking & 61.3 & 50.0 & 66.7 & n.s. \\
\hline & Horseback riding & 5.3 & 25.0 & 33.3 & $* * *$ \\
\hline & Butter-making & 45.3 & 45.8 & 70.0 & $*$ \\
\hline & Cheese-making & 16.0 & 16.7 & 20.0 & n.s. \\
\hline & Ice cream-making & 28.0 & 16.7 & 30.0 & n.s. \\
\hline & No. provided services & 4.2 (items) & 3.3 (items) & 4.4(items) & n.s. ${ }^{\text {a) }}$ \\
\hline \multirow{7}{*}{$\begin{array}{l}\text { Direct selling } \\
\text { products }\end{array}$} & Fresh milk & 20.0 & 54.2 & 63.3 & $* * *$ \\
\hline & Ice cream & 25.3 & 66.7 & 66.7 & $* * *$ \\
\hline & Soft cream & 17.3 & 62.5 & 66.7 & $* * *$ \\
\hline & Cheese & 14.7 & 45.8 & 46.7 & $* * *$ \\
\hline & Yogurt & 13.3 & 37.5 & 46.7 & $* * *$ \\
\hline & Ham, sausage & 1.3 & 16.7 & 20.0 & $* * *$ \\
\hline & No. marketed products & 0.9 (items) & 2.8 (items) & 3.1 (items) & $* * *^{\mathrm{a})}$ \\
\hline \multicolumn{6}{|c|}{ Source: Same as Table 2.} \\
\hline \multicolumn{2}{|c|}{ Notes:1) Signs of significance level are in Table 2.} & & & & \\
\hline
\end{tabular}


Furthermore, we can recognise that generally a recreational function such as rural tourism is compatible with the educational function because one fourth to one third of open farms provide lodging services, which is far higher than on normal dairy farms.

On the other hand, there is an apparent contrast in provision of farming experience services. For instance, the uptake of dairy farming experiences tends to be lower in family corporate farms: dairy operation experience (family $63 \%$, family corporate $38 \%$, non-family corporate $47 \%$ ) and coming into contact with livestock (family $49 \%$, family corporate $8 \%$, non-family corporate $37 \%$ ). These services are originally part of the daily production process carried out in the farmyard, so no additional facility is required, unlike that for making milk products and horseback riding. This is why operators of family farms prefer to offer these daily conducted types of services.

Thus, family corporate farms are more likely to diversify their farm activities rather than to offer farming experience services. This is probably because they are committed to diversified activities such as making and selling dairy products by themselves. Therefore, providing farming experience services becomes a supplementary activity for promotion of direct selling of their products. This is a rational attitude under the resource constraints such as labour and facility. In contrast, family farms are only modestly diversified; they have a lower portion of farms offering dairy products for direct marketing and they sell fewer kinds of products than either type of corporate farm ( $1 \%$ significance, one product offered by family farms, three products by corporate farms).

In summary, non-family corporate farms are active both in offering farming experience services and in diversification. This is probably because their resource endowment such as facilities and labour enables them to do that. Family corporate farms actively diversify through manufacturing milk products while family farms are not as active in this direction. Put differently, instead of putting resources to use for diversification in milk processing, family farms can provide more farming experience services.

Thus, it is of interest that differences in performance of educational function and diversification depend on the management policy of owners, i.e., whether or not farms are corporate. Eventually, we can say that farming experience services offered by family farms have tighter jointness than other types of farms because these services are based on the farming operations that are conducted daily. Therefore, it is difficult to separately produce commodity, i.e. dairy products, and non-commodity goods, i.e. educational function, on family farms. All these facts indicate that there is not any correlation between farm size and the educational function.

\section{Conclusions}

The aim of this paper was to clarify conceptual and empirical characteristics of the educational function of agriculture. We investigated the relationship between jointness and farm structure by focusing on Open Dairy Farms in Japan. The following are the main findings although we should take into account the upper 
bias that the data have in terms of farm size and constraints on available data that restricts interpretation.

The results of statistical tests reveal that Educational Dairy Farms are proactive in offering an educational function among the Open Dairy Farms. This means that the program of Educational Dairy Farms enhances the institutional jointness of the educational function. Moreover, family farms and non-family corporate farms among the Open Dairy Farms offer a higher educational function than family corporate farms that are more oriented toward diversification.

To conclude, the educational function of dairy farming has no correlation with farm size, but requires a certain level of farm size, which means this externality is decoupled with farm size and that there is a necessary condition of farm size for generating this externality. The jointness is not fixed, but variable. Among other things, family farms certified as educational dairy farms have firmer technical and institutional jointness, therefore there can be less substitution of other similar educational services.

Consequently, policy implications are as follows: the educational function does not have a production-stimulating effect and a policy program aiming at promotion of this function is effective, especially for family farms. It is safe to say that these family farms play a role in filling a gap caused by declining educational capability in society despite knowledge of incomplete internalisation of their generating externalities, which is a unique feature of educational function. This will be the reason for supporting promotion of such educational capabilities of dairy farms on the one hand while, on the other hand, farmers' efforts should be made for internalisation by combining the educational function with other similar diversified activities such as rural tourism.

\section{References}

[1] Hagedorn, K., Rethinking the Theory of Agricultural Change in An Institution of Sustainability Perspective, Van Huylenbroeck, G., Verbeke, W., Lauwers, L., Vanslembrouck, I. and D' Haese, M. eds. Importance of Policies and Institutions for Agriculture, Academia Press: Ghent, 33-56, 2003.

[2] Ohe, Y., Farm Pluriactivity and Contribution to Farmland Preservation: A Perspective on Evaluating Multifunctionality from Mountainous Hiroshima, Japan, Japanese Journal of Rural Economics, 3, 6-50, 2001.

[3] Ohe, Y., Multifunctionality and Farm Diversification: A Direction of Farm Policy, Full papers of the 80th EAAE Seminar New Policies and Institutions for European Agriculture CD-ROM, Ghent, 1-13, 2003.

[4] OECD, Multifunctionality: Towards an Analytical Framework, Paris, 2001.

[5] OECD, Multifunctionality: The Policy Implications, Paris, 2003.

[6] Shichinohe, C., Nagata, K. and Jinnouchi, Y., Educational Function of Agriculture (in Japanese), Rural Culture Association (Nobunkyo): Tokyo, 1990.

[7] Van Huylenbroeck, G. and Durand, G., Multifunctional Agriculture: A New Paradigm for European Agriculture and Rural Development, Ashgate Pub Co.: Aldershot, 2003. 